\title{
KADAR OKSIGEN TERBAIK SEBAGAI DAYA TARIK WISATA KESEHATAN PADA PULAU GILI IYANG
}

\author{
Aryo Wibisono ${ }^{1}$ \\ Anik Anekawati ${ }^{2}$ \\ Suci Annisa ${ }^{3}$ \\ ${ }^{1}$ FEB Universitas Wiraraja, Indonesia \\ laryo.feb@wiraraja.ac.id \\ Suci Annisa ${ }^{3}$ \\ ${ }^{2}$ FKIP Universitas Wiraraja, Indonesia \\ 2anik@wiraraja.ac.id
}

\begin{abstract}
With so many coastal areas in Indonesia, it can provide a lot of potential that can be exploited such as the potential for fisheries, marine, agriculture, energy and tourism. One of the potentials that are in great demand by people is tourism. The potential for coastal tourism will have a beneficial impact on both the government and local communities living around the coastal areas if it can be managed properly. This study aims to determine the basis for determining Gili Iyang as a health tourism destination. To find out the role of the local village head in making Gili Iyang a health tourism destination. To find out the opinions of tourists who have visited Gili Iyang. To determine the role of oxygen levels in the human body. And the results of the research. From the results of this study, it can be concluded that the development of the island of Gili Iyang as tourists is still not fully able to run smoothly, because there are still several supports that need to be maximized. For example, there is a study on health on Gili Iyang Island so that later this island will be known for its health tourism. In addition, it would be better if you add several places to attract tourists visiting the island.
\end{abstract}

Keywords : Gili Iyang, Health tourism, Oxygen

\section{PENDAHULUAN}

Indonesia merupakan negara kepulauan, karena wilayahnya membentuk pulau - pulau yang di kelilingi oleh lautan serta sebagian wilayahnya merupakan pesisir yang sangat luas dan membentang dari Sabang hingga Merauke. Dengan banyaknya wilayah pesisir yang berada di Indonesia maka dapat memberikan banyak potensi yang bisa dimanfaatkan seperti potensi perikanan, kelautan, pertanian, energi dan juga pariwisata. Salah satu potensi yang banyak diminati oleh orang adalah pariwisatanya. Potensi wisata pesisir akan dapat berdampak keuntungan baik untuk pemerintah serta masyarakat lokal yang tinggal di sekitar wilayah pesisir jika bisa dikelola dengan baik (Hidayat, 2011).

Setelah beraktivitas yang cukup berat sehari - hari dan cukup penat maka seharusnya setiap manusia memerlukan namanya 


\section{FAKULTAS EKONOMI DAN BISNIS UNIVERSITAS WIRARAJA - MADURA}

berwisata supaya tidak jenuh dan pikiran akan menjadi relaks yang nantinya akan membangkitkan semangat dalam menjalankan rutinitas lagi. Dan untuk memulihkan pikiran maka hendaknya berwisata, salah satunya wisata alam sebagai alternatif wisata yang dapat memulihkan tenaga dan pikiran. Dan wisata kesehatan dapat juga menjadi pilihan bagi masyarakat perkotaan yang ingin menikmati waktu luang untuk mengembalikan kebugaran dan dapat meningkatkan kesehatan mereka dikarenakan aktifitas yang padat.

Salah satu wilayah yang memiliki oksigen terbaik di dunia terletak pada Kabupaten Sumenep khususnya pada Pulau Gili Iyang bedasarkan penelitian oleh (Balai Besar Tekhnis Kesehatan Lingkungan dan Pengendalian Penyakit Jawa Timur (BBTKLPP) serta penelitian dari Lembaga Penerbangan dan Antariksa Nasional, 2006). Dan terdapat penelitian yang dilakukan oleh (Husamah, Fatmawati, Setyawan, \& Miharja, 2018)dari hasil penelitiannya didapatkan bahwa oksigen dengan kadar yang tinggi dibutuhkan dalam beberapa pasien tertentu, seperti sesak nafas akibat asma dan gagal jantung. Terapi oksigen tersebut harus dalam pengawasan tenaga medis yang ketat, sebab jika overdosis dapat menjadikan hiperoksia atau keracunan oksigen. Menurut (Zainuri, Faizin, \& Salamet, 2018)Jadi meskipun oksigen sangat vital dibutuhkan tubuh, kadar yang tinggi juga perlu diwaspadai karena bisa memicu keracunan oksigen atau hiperoksia.

Oleh karena itu dari pemerintah setempat berupaya untuk melakukan perbaikan supaya pulau tersebut dapat menjadi rujukan sebagai wisata kesehatan. Menurut (Wibisono \& Destryana, 2018) dari hasil penelitiannya jika pemerintah setempat memberika pelayanan salah satunya berupa pelayanan kesehatan maka masyarakat akan merasakan puas dari pelayan pemerintahannya.

Selain menyimpan kadar oksigen yang baik, di Pulau Gili Iyang juga menyimpan beberapa keindahan alam yang perlu di kunjungi, ada pantai serta gua yang tidak kalah menarik dengan wisata alam di tempat lain. Di Pulau Gili Iyang sangat di jaga keindahannya 
oleh masyarakat sekitar mulai dari kebersihan serta polusi kendaraan sehingga akan tetap terjaga kebersihan udara yang berada di Pulau Gili Iyang. Dengan adanya wisata alam yang berada pada Pulau Gili Iyang diharapkan akan memberikan dampak yang besar bagi masyarakat sekitar.

\section{TINJAUAN TEORITIS}

\section{Pemasaran}

Pemasaran adalah seluruh dari kegiatan usaha yang ditujukan untuk merencanakan, menentukan harga, mempromosikan, dan mendistribusikan barang dan jasa yang dapat memuaskan kebutuhan konsumen, (Stanton, 2012).

\section{Pemasaran Pariwisata}

Menurut (Leroux \& Pupion, 2014) merumuskan pemasaran pariwisata adalah sebagai berikut " Pemasaran di bidang pariwisata dipahami sebagai pelaksanaan kebijakan bisnis yang sistematis dan terkoordinasi oleh pengusaha pariwisata baik milik swasta maupun milik negara di tingkat lokal, regional, nasional, dan internasional untuk mencapai pengembalian yang sesuai.

Pemasaran pariwisata adalah suatu system dan koordinasi yang harus dilakukan sebagai kebijaksanaan bagi perusahaan-perusahaan kelompok industry pariwisata, baik milik swasta maupun pemerintah, dalam ruang lingkup lokal, regional, nasional, atau internasional untuk mencapai kepuasan wisatawan dengan memperoleh keuntungan yang wajar.

\section{Pariwisata}

Menurut (Pendit, 2004), mendefinisikan Pariwisata sebagai suatu proses kepergian sementara dari seseorang atau lebih menuju tempat lain di luar tempat tinggalnya. Dorongan kepergiannya adalah karena berbagai kepentingan, baik karena kepentingan ekonomi, sosial, kebudayaan, politik, agama, kesehatan maupun kepentingan lain seperti karena sekedar ingin tahu, menambah pengalaman ataupun untuk belajar.

\section{Obyek Wisata}

Menurut (Suwantoro, 2004) menjelaskan obyek wisata merupakan potensi yang menjadi pendorong kehadiran wisatawan ke suatu daerah. Selanjutnya obyek wisata ini dikelompokkan menjadi tiga golongan : 
a. Obyek wisata dan daya tarik wisata alam Obyek wisata yang daya tariknya bersumber pada keindahan dan kekayaan alam.

b. Obyek wisata dan daya tarik budaya Obyek dan daya tarik bersumber pada kebudayaan, seperti peninggalan sejarah, museum, atraksi kesenian, dan obyek lain yang berkaitan dengan budaya.

Obyek wisata dan daya tarik pada minat khusus Obyek wisata daya tariknya bersumber pada minat khusus wisatawan itu sendiri, misalnya olah raga, memancing, keindahan alam, dll.

\section{Oksigen}

Oksigen diperlukan sel untuk mengubah glukosa menjadi energi yang dibutuhkan untuk melakukan berbagai aktivitas, seperti aktivitas fisik, penyerapan makanan, membangun kekebalan tubuh, pemulihan kondisi tubuh, juga penghancuran beberapa racun sisa metabolisme (Nikmawati, Windarwati, \& Hardjoeno, 2018)

\section{METODE}

\section{Tahapan Penelitian}

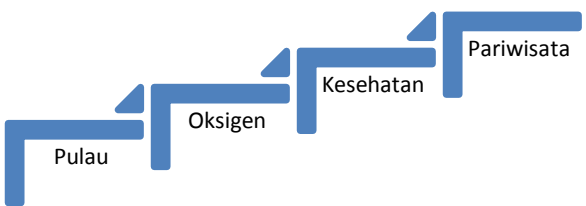

Penelitian ini dilakukan bedasarkan bagan diatas ialah dari beberapa literatur yang telah di baca pulau Gili Iyang ini mempunyai beberapa potensi untuk dapat dikembangkan, salah satunya adalah adanya kadar oksigen yang tinggi. Kadar oksigen yang baik bagi kesehatan manusia, sehingga nantinya dari kadar oksigen yang tinggi ini diharapkan mampu menjadikan daya tarik wisatawan yang ingin berkunjung di pulau tersebut. Terutama untuk wisata kesehatan (perlu kajian khusus supaya pulau Gili Iyang ini dapat dijadikan sebagai wisata kesehatan). Karena masih sangat minim wisata yang mengangkat tentang kesehatan, biasanya wisata alam, pantai, dll. Sehingga ini sangat menarik untuk diperdalam dan dikembangkan supaya menjadikan pulau Gili Iyang ini sebagai rujukan bagi orang - 
orang yang ingin berwisata, terutama yang ingin merasakan kesejukan dari kadar oksigen yang tinggi ini.

\section{Tempat dan Waktu Penelitian}

Tempat penelitian yang diteliti yaitu objek Wisata Oksigen Giliyang, dimana peneliti mengumpulkan data dari hasil wawancara dengan Kepala Desa, Dosen kesehatan, dan pengunjung yang pernah berkunjung ke objek wisata. Penelitian ini dilakukan dari bulan Juni - November 2020.

\section{Jenis Data}

Data Subjek

Merupakan suatu jenis data yang dapat digolongkan seperti opini atau pendapat seseorang, yang dapat dijadikan sebagai informan.

Data Dokumentasi

Merupakan suatu jenis data yang berwujud. Seperti surat - surat, hasil dari artikel penelitian yang nantinya dapat dijadikan sebagai bahan pendukung penelitian.

\section{Sumber Data}

Sumber data yang ada pada penelitian ini ialah sebagai berikut:

1. Data primer merupakan hasil dari wawancara terhadap informan.

2. Data sekunder merupakan data pendukung dalam penelitian ini seperti hasil kutipan dari artikel serta dokumentasi foto.

\section{Informan}

Penentuan informan dalam penelitian ini didasarkan pada informan yang dipilih langsung oleh peneliti yaitu mereka yang mempunyai kapabilitas sesuai dengan yang diharapkan oleh peneliti sebagai informasi. Maka dalam penelitian ini yang menjadi informan diantaranya :

1. Informan kunci dan Informan utama: Bapak H. Mathor, SH., MM. selaku Kepala Desa Banraas

2. Informan pendukung dari segi kesehatan : Bapak Dr. Eko Mulyadi, S.Kep., Ns., M.Kep selaku dosen FIK Universitas Wiraraja

3. Informan pendukung dari segi pengunjung : R. Habibullah

\section{Teknik Pengumpulan Data}

Metode Observasi

Merupakan salah satu cara dimana peneliti mengadakan peninjauan dan penelitian langsung pada destinasi wisata yang ada di giliyang. Untuk memperoleh data tersebut, hasil-hasil yangdidapat dicatat dengan cermat 
dan teliti sebagai data yang dibutuhkan.

Metode Wawancara (Interview)

Merupakan tanya jawab antara pewawancara dengan yang mewawancarai untuk meminta keterangan atau pendapat mengenaisesuatu hal. Dalam pengumpulan data melaui wawancara, penulis langsung mengadakan tanya jawab dengan para pengelola atau pemilik usaha destinasi wisata yang ada di Giliyang, dan pemilik usaha wisata tersebut berwenang memberikan informasi data yang dibutuhkan oleh peneliti.

\section{Metode Dokumentasi}

Merupakan teknik pengumpulan data dimana sejumlah besar fakta dan data tersimpan dalam bahan yang berbentuk dokumentasi. Sebagian data yang tersedia adalah bentuk berkas-berkas, daftar kontribusi dan kebersihan pedagang, foto dan sebagainya.

\section{Teknik Analisis Data}

Supaya dalam melakukan sebuah penelitian lebih terukur maka perlu adanya tahapan-tahapan untuk melakukan penelitian tersebut.
Berikut ini merupakan tahapan penelitian itu adalah:

\section{Tahapan Pra Lapangan}

Untuk tahapan ini peneliti mengumpulkan data - data yang akan dibutuhkan untuk terjun ke lapangan.

\section{Tahapan Pekerjaan Lapangan}

Dalam tahapan ini peneliti melakukan diskusi dengan kepala desa setempat untuk melakukan pengumpulan data yang diperlukan.Dan melakukan beberapa point dalam penelitian kualitatif seperti :

Reduksi data

Yaitu melakukan perumusan sebuah permasalahan yang ada di lapangan serta mencari teori yang mendukung. Penyajian data

Yaitu menampilkan sebuah informasi dari hasil di lapangan yang berupa hasil dari wawancara yang menjawab dari perumusan masalah dari penelitian ini.

Verifikasi/kesimpulan

Yaitu dari hasil yang sudah didapatkan maka akan dapat ditarik sebuah kesimpulan yang nantinya bisa memberikan sebuah informasi bagi yang membutuhkan. 
Gambar 2.

Pulau Gili Iyang Melalui Satelit

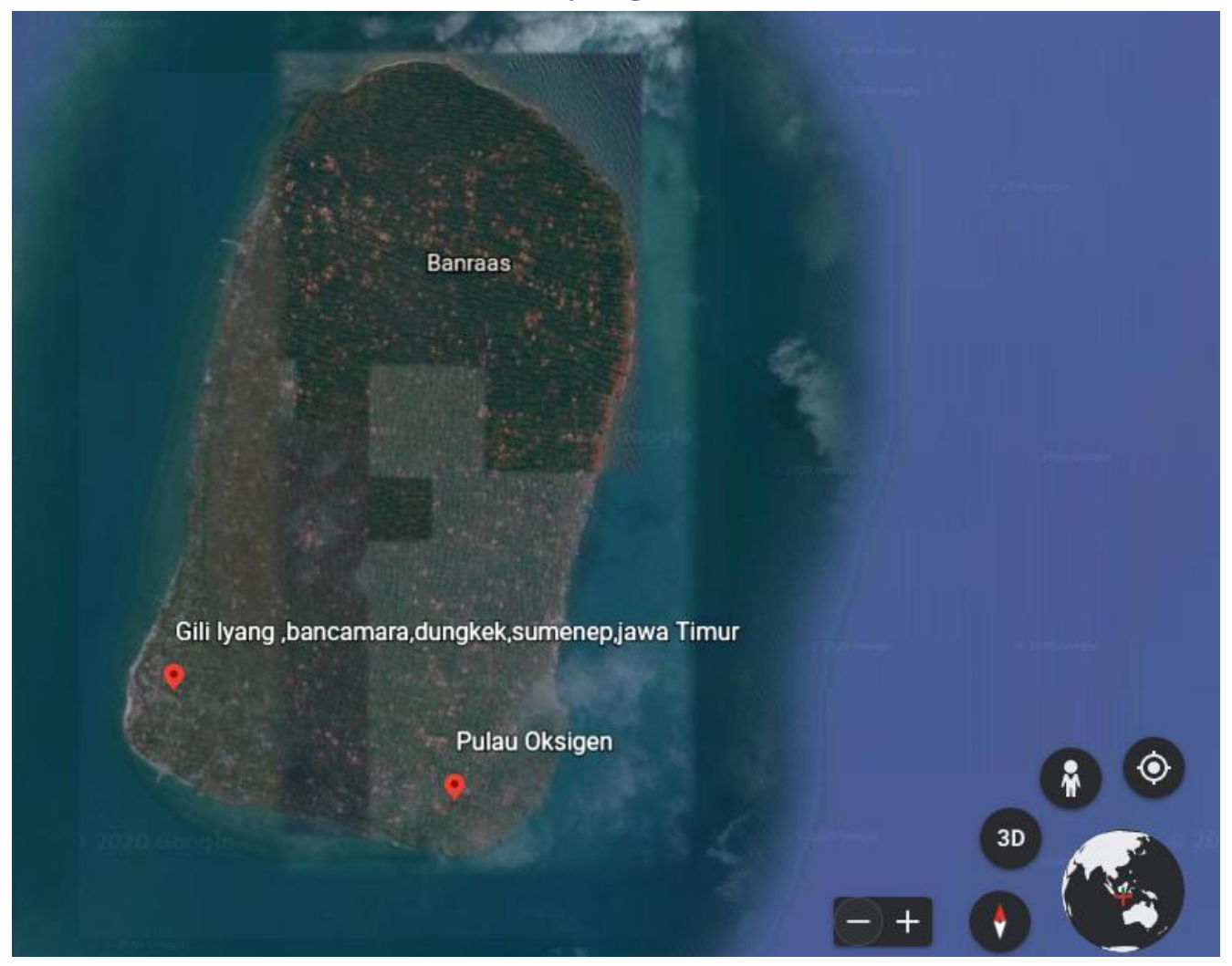

Secara geografis Pulau Gili Iyang berada pada koordinat $0659^{\circ}$ 9” LS Dan 114 10`29” BT dengan luas 921.1 Ha. Sedangkan secara administratif Pulau Gili Iyang berada pada wilayah Kecamatan Dungkek, Kabupaten Sumenep, Provinsi Jawa Timur. Dari pendapatpara sesepuh di sana, asal mulanya Pulau Gili Iyang ditemukan oleh orang Mandar yang mempunyai nama Daeng Masalleh sekitar tahun 1926.Dapat dikatakan bahwa Daeng Massaleh disebut sebagai orang pertama kali yang mengeksplor seluruh Pulau Gili Iyang.

\section{Hasil Penelitian}

\section{Dasar penetapan Gili Iyang} sebagai destinasi wisata kesehatan

Pada dasarnya setiap memberikan suatu slogan atau bisa dibilang julukan pada suatu tempat maka diharuskan memiliki dasar dasarnya, karena tidak mungkin memberikannya tanpa dasar, sehingga nantinya dasar tersebut yang dibuat untuk mempertahankannya dan dapat juga untuk nantinya bisa dikembangkan. 
Untuk Pulau Gili Iyang ini sendiri mendapatkan julukan sebagai Pulau yang memiliki kadar oksigen yang terbaik di dunia. Pemberian nama ini tidak lepas dari adanya sebuah penelitian dari LAPAN yang pada saat itu melakukan pengukuran oksigen pada beberapa titik di Pulau Gili Iyang. Sehingga dari hasil penelitian itulah Pulau Gili Iyang saat ini di sebut - sebut sebagai Pulau dengan kadar oksigen terbaik di dunia.

Untuk memperkuat dasar ini maka dilakukan wawancara kepada kepala Desa Banraas atas nama Bapak $H$. Mathor sebagai berikut :

، Pada awalnya Pulau Gili Iyang ini hanya sebagai Pulau biasa, dan pada saat itu ada team dari LAPAN yang melakukan penelitian di Pulau kami. Dari hasil penelitiannya setelah melakukan pengukuran di 12 titik ditemukanlah kadar oksigen yang tinggi dari titik titik tersebut, sehingga dari hasil penelitian tersebut Pulau kami terkenal dengan Pulau yang memiliki kadar oksigen yang tinggi. Sehingga dari hasil penelitian dari LAPAN tersebut, Pulau kami terkenal dengan Pulau dengan kadar oksigen terbaik. Sehingga banyak sekali wisatawan yang datang ke Pulau kami untuk merasakan kadar oksigen tersebut, sehingga dari sana kami berkeinginan untuk menjadikannya wisata kesehatan bagi siapa saja yang memerlukan kesegaran dari kadar oksigen bisa datang ke Pulau kami untuk merasakannya. Tetapi kami ingin ada yang melakukan penelitian tentang hal tersebut, sehingga akan memperkuat bahwa Pulau kami bisa menjadi wisata kesehatan bagi wisatawan yang datang........."

\section{Peran kepala desa setempat dalam menjadikan Gili Iyang sebagai \\ destinasi wisata kesehatan}

Pada setiap Desa pastinya memiliki Kepala Desa yang berperan dalam mengembangkan Desanya supaya dapat berkembang dan mandiri. Ada beberapa cara supaya menjadikan Desa dapat berkembang salah satunya melihat potensi Desa tersebut, jadi nantinya Desa tersebut mau dijadikan seperti apa.

Nah pada Pulau Gili Iyang ini mimiliki Desa dengan potensi alam yang luar biasa, ada gua, pantai dan yang paling terkenal dikalangan masyarakat adalah kadar oksigennya yang tinggi, sehingga salah satunya menjadi daya tarik bagi wisatawan yang ingin berkunjung ke Madura khususnya ke Pulau Gili Iyang. Sehingga perlu bagi Kepala Desa untuk mengembangkan Desanya ke arah wisata alam sehingga dapat 
menarik minat wisatawan yang berkunjung ke Pulau Gili Iyang.

Oleh karena itu dilakukan wawancara terhadap Kepala Desa dan Perangkat Desa tentang pengembangan dari Desanya. Berikut hasil wawancaranya :

“......Awalnya saya bingung, kira - kira Pulau kami mau diarahkan kemana supaya dapat mensejahterakan masyarakat sekitar. Nah dengan adanya hasil penelitian tersebut maka saya bersama perangkat Desa mulai memikirkan untuk membuat sebuah wisata yang berkaitan dengan kadar oksigen ini, maka kami putuskan untuk menjadikannya wisata kesehatan. Selain itu ada juga tempat wisata di tempat kami, seperti pantai dan gua - gua yang bisa dijadikan sebagai tempat wisata bagi para wisatawan. Selain itu kami juga menyediakan tempat buat bermalam bagi wisawatan yang ingin berkunjung ke Pulau kami, dan bila banyak yang berkunjung malamnya kami memberikan tontonan seperti tarian daerah untuk memberikan suguhan bagi para wisatawan serta mengenalkan budaya kami kepada mereka....."

Pendapat wisatawan yang telah berkunjung ke Gili Iyang

Pada dasarnya setiap tempat wisata terdapat kunjungan dari wisatawan baik dalam negeri maupun luar negeri. Demi memberikan kenyaman terhadap para pengunjung maka pengelolah meminta pendapat dari para pengunjung tentang bagaimana kekurangan dan apa saja yang perlu dikembangkan, sehingga tempat wisata tersebut menjadi ramai dan banyak dikunjungi oleh para wisatawan.

Pada Pulau Gili Iyang saat ini, dengan adanya wabah penyakit Covid 19 pengunjung wisatawan mengalami penurunan dikarenakan banyak yang menunda bahkan membatalkan kunjungannya ke Pulau tersebut.

Tetapi tetap ada yang berkunjung ke Pulau Gili Iyang dengan protokol kesehatan sesuai dengan anjuran pemerintah, sehingga dapat di minta pendapatnya tentang Pulau Gili Iyang. Berikut hasil wawancaranya dengan pengunjung :

“........Pertama kali saya ke sini, ya sebenarnya saya agak takut dikarenakan harus menaiki perahu untuk menyeberang ke Pulau perjalanan sekitar kurang lebih 30 menitan. Bagi yang mabuk laut bisa minum antimo dan sejenisnya ya biar tidak mabuk laut, hehehe. Sesampainya di Pulau ya mungkin habis panas - panasan 
dengan menaiki perahu terasa segar udaranya, Pulaunya nyaman orang - orangnya juga baik semua. Tetapi memang kalau hanya sehari di Pulau ini terasa kurang dan tidak bisa merasakan kenyamanan Pulau ini. Sehingga paling tidak bermalam baru bisa merasakannya. Yang kurang dari pulau ini mungkin minimnya hiburan dan permainannya sehingga agak boring juga, serta kurangnya yang menjual makanan dan minuman sehingga yang ingin ke sini diharapkan membawa sendiri kebutuhannya........."

\section{Peran Kadar Oksigen Terhadap}

\section{Tubuh Manusia}

Pada setiap makhluk hidup pasti membutuhkan oksigen, baik itu tumbuhan, binatang serta manusia. Oleh karena itu oksigen sangat mempunyai peran penting terhadap makhluk hidup untuk bernafas. Dan untuk orang sakit sendiri pasti memerlukan oksigen dalam penyembuhannya.

Pada Pulau Gili Iyang sendiri memiliki julukan atau terkenal dengan nama Pulau oksigen, karena bedasarkan hasil pengukuran dari penelitian LAPAN ditemukan beberapa titik yang terdapat kadar oksigen yang tinggi.
Oleh karena itu untuk memperkuat

hal tersebut, penelitian ini melakukan

wawancara dengan informan yang

memahami tentang oksigen yang

terlarut bagi kesehatan tubuh

manusia.

Berikut ini hasil wawancara dengan informan dari pakar kesehatan yaitu bapak Eko Mulyadi sebagai berikut :

“..........oksigen merupakan suatu elemen yang dibutuhkan oleh setiap manusia, tanpa adanya oksigen maka manusia akan mengalami gangguan kesehatan. Oksigen dengan kadar yang tinggi dibutuhkan dalam beberapa pasien tertentu, seperti sesak nafas akibat asma dan gagal jantung. Terapi gas oksigen bisa untuk pengobatan awal penderita hipoksiadan juga orang yang terkena paparan radiasi. Terapi oksigen tersebut harus dalam pengawasan tenaga medis yang ketat, sebab jika overdosis dapat menjadikan hiperoksia atau keracunan oksigen. Selain itu oksigen juga dapat berbahaya bagi manusia, karena kadar oksigen yang tinggi juga perlu diwaspadai karena bisa memicu keracunan oksigen atau hiperoksia. Penggunaan kadar oksigen yang tinggi hanya boleh dilakukan dengan pengawasan dari tenaga medis, Dampak dari hiperoksia tersebut bisa berupa kejang-kejang yang dikenal dengan nama Bert effect, sesak nafas yang disebut Smith effect, dan juga bisa menyebabkan kebutaan......." 


\section{KESIMPULAN}

Dari hasil penelitian ini dapat diambil kesimpulan bahwa dengan akan dikembangkannya pulau Gili Iyang ini sebagai wisatawan masih belum sepenuhnya dapat berjalanan dengan lancar, dikarenakan masih ada beberapa penunjang yang perlu dimaksimalkan. Seperti adanya studi tentang kesehatan di Pulau Gili Iyang sehingga nantinya pulau ini akan dikenal dengan wisata kesehatannya. Selain itu akan lebih baik jika ditambahkan beberapa tempat untuk menarik minat wisawatan yang akan berkunjung ke pulau tersebut. Dan perlu dikembangkan tempat wisata wisata di sana, sehingga pengunjung tidak monoton dan tidak bosan. Oksigen memang baik bagi tubuh manusia, tetapi juga dapat membahayakan bagi manusia karena jika terlalu banyak menghirup oksigen dalam tubuh maka akan menimbulkan hiperoksia bagi tubuh manusia.

\section{SARAN}

Saran bagi kepala desa beserta jajarannya, jika memang pulau Gili Iyang ini akan dijadikan tempat wisata kesehatan, maka perlu dipersiapkan dengan baik apa saja yang diperlukan untuk menunjang kegiatan tersebut. Sehingga pulau ini siap jika ada yang berkunjung dengan tujuan wisata kesehatan

\section{DAFTAR PUSTAKA}

Hidayat, M. (2011). Strategi perencanaan dan pengembangan objek wisata (studi kasus pantai Pangandaran Kabupaten Ciamis Jawa Barat). THE Journal: Tourism and Hospitality Essentials Journal, 1(1), 33-44.

Husamah, H., Fatmawati, D., Setyawan, D., \& Miharja, F. J. (2018). Problematika pengelolaan ekowisata Gili Iyang: Perspektif community based ecotourism. Prosiding Seminar Nasional Pendidikan Biologi.

Leroux, E., \& Pupion, P.-C. (2014). Management du tourisme et des loisirs. Vuibert.

Nikmawati, A., Windarwati, W., \& Hardjoeno, H. (2018). Resistensi Mycobacterium tuberculosis terhadap Obat Anti Tuberkulosis. Indonesian Journal of Clinical Pathology and Medical Laboratory, 12(2), 58-61.

Pendit, N. S. (2004). Ilmu Pariwisata Sebuah Perdana. Penerbit Pradinya Paramita, Jakarta.

Stanton, W. J. (2012). Prinsip pemasaran, alih bahasa: Yohanes Lamarto Penerbit Erlangga. Jakarta.

Suwantoro, G. (2004). Di dalam bukunya Dasar-dasar Pariwisata. Yogyakarta: Penerbit Andi. 
Wibisono, A., \& Destryana, R. A. (2018). PELAYANAN PUBLIK KESEHATAN PUSKESMAS DALAM MEMBERIKAN KEPUASAN MASYARAKAT DI KABUPATEN SUMENEP. Jurnal Riset Manajemen Dan Bisnis (JRMB) Fakultas Ekonomi UNIAT, 3(3), 321-330.
Zainuri, A. M., Faizin, A., \& Salamet, S. (2018). Revitalisasi Kawasan Pulau Giliyang sebagai Destinasi Wisata Kesehatan di Kabupaten Sumenep. Jurnal Dedikasi, 15. 